\title{
Dealing with the Past in the Days of the Covid 19 Pandemic: The Higher Education Sector in South Africa
}

\author{
Mokgadi Molope
}

\section{Introduction}

The end of most dictatorships world-wide ushered in a moment for countries to introduce new governance, political and economic systems. It was up to the new governments to determine the characteristics of such a new dawn. Lambourne (2014) argues that while in some countries conscious decisions were taken to punish the perpetrators and violators of human rights through mass killings and torture, others opted to confront them through truth commissions which led to some people receiving amnesty while others got prison sentences. South Africa elected the latter. At the dawn of democracy, the country began a democratisation process aimed at transforming the social, political, economic, and environmental configuration to reflect the will of most of the people. The constitution of the country commands the transformation process and the country's development process to be guided by principles of accountability, equality, responsiveness, openness, non-racialism, non-sexism and advancement of human rights and freedoms. This constitution is a contract between the government and citizens guaranteeing that these constitutional principles are upheld by all and that the citizens enjoy their constitutional rights while the government carries out its constitutional mandate. At the centre of these constitutional imperatives is the need to assure that political dispensation translates into opportunities for the previously oppressed and conquered people to ensure their epistemology and philosophy are not ignored (Ramose, 2004).

In pursuit of its constitutional obligations, and as part of the transition from an oppressive governance system towards democracy, the South African government adopted a consultative approach to solidly establish a democratic system based on the principle of everyone's equality before the law as stated in the constitution. This consultative approach was chosen to avoid oppression of one person, race, or sex over another. At the centre of this was the reconciliation agenda. This agenda is part of an important collective memory, on whose basis the future is supposed to be built. The 
position stems from the recognition of past injustices committed against Black South African people and the quest for a peaceful and prosperous country whose citizens live together in harmony under the rule of law.

In this article, Black South Africans refers to all those who were not given the right to vote and suffered immensely at the hands of different development protagonists. These protagonists enjoyed making Blacks suffer during the apartheid era. The actions of these perpetrators were unfortunately protected by the laws of the country at that time. Legal as they were, these laws were inhumane. During this brutal era, many lost lives, family members, property and their human dignity. This resulted from the fact that the apartheid governance system was structured in such a manner that on paper it gave equal opportunity to all races to grow and develop on their own without interference from another racial group. In practice, however, this separation promoted domination of whites over Blacks because the white minority government gave economic, social, and political privileges to whites only. The privileges created opportunities for white people to prosper as they had the right to vote and thus to decide on policies that were oppressive to Blacks. They also received subsidies which boosted them financially and sustained their income generating ventures. Furthermore, they were given access to productive land, quality basic social services, health care and education.

Conversely, most of the Black South Africans' human rights were violated in a number of ways. They were restricted from moving within the country through laws such as the Group Areas Act. They were thus squashed in homelands, reserves, and unproductive pieces of land where there were no basic services nor activities to generate meaningful income. Consequently, these spaces became a pool of cheap labour for whites. Only a few Blacks were able to produce and become key role players in the economy. The system also produced an elite class that emerged from collaborating with whites to oppress Black people. The result was that many Blacks became impoverished and were forced to rely on subsistence production which lost labourers because of the migrant labour system. The latter was not helpful due to the low paying jobs whose salaries could not meet the needs of the families let alone sustain and support subsistent production and contribute to its conversion to commercial production. The system further contributed to the disintegration of families and communities. This racially based differential treatment engineered inequality among South Africans and the Black South Africans were the hardest hit as they were treated as second class citizens.

Surprisingly, these victims empowered themselves by opting for reconciliation rather than retaliation (Villa-Vicencio, 2012). Be that as it may, 
the decision to reconcile was the best for the country politically, as it was aimed at transforming the structural social and economic discrimination in the country. It was meant to pave the way for the country to deal with the injustices which led to Black South African people living in appalling conditions characterised by poverty, high unemployment, and poor-quality social services such as water, health and education. The latter was not only of poor quality, but it was used to control Black South African people to ensure that the majority did not study disciplines that would afford them opportunities for self-sufficiency and thus meaningfully contribute to the development of the country (Odero, 2017). The curriculum, as observed by Uzomah (2018), was European centred and critical of other forms of knowledge, which were discredited and portrayed as useless to the development agenda as noted by Dunga and Mncayi (2016).

\section{Truth and Reconciliation Commission and Higher Education in South Africa}

After the end of apartheid, the Promotion of National Unity and Reconciliation Act No 34 of 1995 was passed by the national parliament. The act made provisions to investigate the gross violation of human rights which occurred in and outside the country during the apartheid era. It was grounded on the notions that the perpetrators would voluntarily give full disclosure of evidence for what transpired. The victims also had an opportunity to express the violations they suffered. These mainly took place in the form of hearings which occurred from 1996. The first and last reports were released in 1998 and 2003, respectively.

This reconciliation process is important in the history of the country because it is one of the instruments adopted by the government to help the nation deal with the past apartheid injustices and human rights abuses in all sectors of society (Simmonds \& du Preez, 2017). The Commission gathered pertinent information by listening to the confessions made by the perpetrators of apartheid crimes against the victims. The solemn purpose was to uncover the truth relating to the nature, causes and effects of these violations. The anticipated output of this process was that the sourced information would be used to facilitate forbearance, reception, and reconciliation across the nation and beyond racial lines. The ultimate goal was to enhance and strengthen the country's healing process (Mamdani, 2002).

The most interesting feature of South Africa's reconciliation process is that the confessions of human rights abuses were sought among all racial groups rather than focusing on one group and ignoring others (Mamdani, 2002). This served as a motivating factor especially among Blacks who 
perpetrated violence on fellow Blacks and whites on their own. To a great extent this illustrates that the Commission's work was not intended as retaliation against any or certain perpetrators but was meant to give all equal opportunity thus promoting the spirit of fairness and equality. These are some of the key requisites for citizens pursuing nation building.

The TRC process is hailed as a good initiative that provided people with the opportunity to admit wrongdoing openly thus building a space for reconciliation. It also provided the country the opportunity to build a memory of its past collectively (Simmonds \& du Preez, 2017). It therefore goes without saying that the institutions of higher education could have contributed to the construction of this memory through the declaration of their role in sustaining the atrocities of the apartheid system. This makes the call by Mamdani (2002), that the TRC process ought to have been centred on the communities as victims as opposed to individuals, more pertinent. Mamdani argues that, as a consequence of this approach, the TRC lost the opportunity to illustrate how the actions undertaken by the higher education institutions constituted a 'crime against humanity'. Consequently, these institutions did not account extensively for the crimes committed in support of the apartheid system.

The humiliation of the Black people of South Africa, suffered during apartheid, needed the recognition of the Truth and Reconciliation Commission not merely as part of a political reconciliation but also as a social and cultural reconciliation. A crucial example is education. According to important evidence from academic work (Dunga \& Mncayi, 2016; Uzomah, 2018) and international organizations, education is an important cornerstone in facilitating development. Consequently, the apartheid regime orchestrated intense efforts through the education sector to ensure that Black South Africans became dependent on other racial groups. They were offered inferior education to prevent them from being innovative and creative, and thus they were unable to develop solutions for their own problems. At the same time, their indigenous knowledge system was criticised, belittled, and never recognised as anything that could make any significant contribution to the country. Contributing to social and cultural reconciliation therefore would have had to include the creation of spaces for a different approach to redress and transform the entire education system, which did not happen, however. This anomaly can still be corrected to make sure the education sector can better manage the current problems and better prepare for the unpredicted moments such as the Covid 19 pandemic that has further exposed the sector's inequalities. This is critical since transformation in higher education has a great potential for triggering social change (Nkomo et al., 2007). 
During apartheid, the institutions of higher learning played a critical role in strengthening and entrenching the violations of human rights through curricular and non-curricular activities. While white universities were seen as centres of excellence characterised by high ratings, talent management, access to resources, good student achievement and highly qualified and experienced academics and researchers, Black universities were seen as peripheral institutions with lack of resources, poor or no ratings, as well as minimal research output (Mamdani, 2016). These differentiations resulted in a well-orchestrated segregated higher education system that ensured that everything from historically Black institutions was inferior.

As the country was in transit to democracy and the Reconciliation Commission started its work, there was a natural expectation from society-especially from victims of racism and abuse of human rights within the higher education sector-that perpetrators of these injustices would confess and admit their deeds. This expectation emerged from the terms of reference of the TRC which made it clear that there was no room for general amnesty, that every person who committed an apartheid offence had to acknowledge what they did. It is for this reason that Villa-Vicencio (2003) encouraged them to account for their racist, discriminatory and segregative acts and behaviour through the TRC. However, little was achieved through this process and it became a missed opportunity for the sector to voluntarily assess and unearth its violation of human rights, construct a process to shed these and craft a future grounded on a reconciliatory foundation. Nevertheless, the move to commit through their mission and vision statements, which embrace protection of human rights and pursuit of fairness, equality, social justice and openness to name a few, is worth applauding. Still, Simmonds and du Preez (2017) warn that it is not sufficient to limit oneself to such statements, but putting them into practice is pertinent, especially by making education accessible to all. It is therefore important for education institutions to implement tangible and practical strategies which allow them to translate their mission and vision statements into material benefits especially for those coming from poor backgrounds. These are only possible if monitoring systems are not only limited to figures, but practical evidence coupled with qualitative narratives which give a clear picture of what is happening on the ground (Mzangwa, 2018).

In summary, the transformation system imagined by the Commission has unfortunately not managed to close the "historical bridge between the past of a deeply divided society characterized by strife, conflict, untold 
suffering, and injustice, and a future founded on the recognition of human rights, democracy and peaceful co-existence for all, irrespective of colour, race, class, belief or sex" (TRC, 2005: 103). The slow progress in bridging this gap does not come as a surprise. The Commission was successful to the extent of exposing apartheid crimes and getting confessions from the perpetrators of human rights violations but some of these were incomplete and lacking credibility (Villa-Vicencio, 2012). Getting the society that was deeply divided by these violations to reconcile requires more than confessions and what seems to be acceptance of these by the majority. This is premised on the reality that these atrocities are continuing in various forms and shapes even today (Mamdani, 2016). Perhaps Villa-Vicencio (2003) had anticipated this when he called for an education specific TRC whose focus would be able to unravel apartheid education sector inequalities thus paving the way for a just society. It is important to note that he also believes that such engagements must focus more on the truth, justice and reconciliation compared to amnesty (Villa-Vicencio, 2012). Putting these at the centre of a social reparation process may assist in creating a peaceful society because people would open up knowing that accepting responsibility will heal both the victim and the perpetrator, which illustrates the Ubuntu principle ${ }^{1}$ (Ramose, 2002).

As a consequence of the lack of structural transformation of the system of (higher) education, Horsthemke (2005) observed that the majority of Black students are outraged by their alma mater. This is because of the oppressive environment that they studied under which promoted preference of one racial group over the other. A very similar argument is expressed about the same system that did not care about its effect on the academics and non-academic staff forced by the circumstances to promote oppressive classroom and outside classroom curriculum.

The outrage and resentment against these institutions are perhaps not misplaced because interventions such as Education White Paper 3 (1997) on the transformation of Higher Education and Education White Paper 6 on 'Building an inclusive education and training system' (2003) as well the Higher Education Act of 1997-to cite a few—set a clear agenda which

1 Ubuntu is a wellspring that flows within African existence and epistemology in which the two aspects Ubu and ntu constitute a wholeness and oneness. As such, ubuntu expresses the generality and oneness of being human. It is also worth noting that ubuntu as an ancient philosophy or worldview has its roots deeply anchored in traditional African life. In this sense the philosophy of hunhu/ubuntu is dialectical, that is, it informs African practice and is in turn enriched by the same practice. 
the higher education institutions had to adopt as a framework for transformation, but which have moved very slowly towards their aim. There has been more engagement on the discourse on how to Africanize, indigenize and decolonize the higher education sector as noted by Simmonds and du Preez (2017). While that is the case, the strides made in the realm of access particularly for Black students are now being eroded by socio-economic factors. High indebtedness among these students prevents them from enjoying access which is given by the sector's policies. These drawbacks find their origin in the segregative past which was orchestrated to sustain separate development thus keeping Blacks at the lowest level of the development echelon. Scholars argue that discussions have been taking place far too long and what needs to be done is to implement the decisions which have been taken.

These experiences have led to bitterness among people in this sector, especially when they realised that the Reconciliation Commission did not do much to hold perpetrators accountable for the 'crimes against humanity' they committed withing this context. The Commission by extension victimised both staff members and students for the second time as a community by not highlighting that their plight was more of a national catastrophe rather than an individual one. It can therefore be argued that this re-ignited decolonisation of the higher education agenda post 2010 in South Africa.

\section{Redress in the Midst of the Covid 19 Pandemic}

While the reality that these are long term processes is acknowledged, the outbreak of the Covid 19 pandemic brought the realization that reconciliation and transformation have been very slow. It exposed the lack of care on the part of authorities for people who were disadvantaged during the apartheid and the post-apartheid era. These authorities have the constitutional obligation to ensure that all children have the right to education (Nkomo et al., 2007). Despite this Constitutional right, not all students-especially those who are from the rural areas, townships and informal settlements - enjoy this basic right. Today, these disadvantaged groups are even more affected because the Covid 19 movement restrictions prohibit them from going to school. As if this wasn't bad enough, because of their socio-economic reality, they are prevented from participating in educational activities due to lack of access to appropriate resources like a phone, laptop and reliable network bandwidth (Mhlanga \& Moloi, 2020). The important question to ponder is whether the need for reliable technol- 
ogy in facilitating online learning should come as a surprise. Right from the beginning of the new dispensation, the government acknowledged the significant role that technology plays to enhance an inclusive learning landscape especially regarding access for marginalised groups which was supposed to be prioritized even then (Odero, 2017).

Unfortunately, the redress that marginal groups qualified for-given in the form of allowances from the National Student Financial Aid Scheme (NSFAS) - could not meet all the needs. While the picture looked bleak for many, there were some students who received support from the same funding agency in the form of laptops. The process faced many challenges such as delays in the allocation process which led to some students receiving these quite late further limiting their distance learning project (Van Schalkwyk, 2020).

In addition to that, the government made commendable efforts to ensure effective learning during the lockdown which benefited students from all walks of life especially the poor (Mhlanga \& Moloi, 2020). For example, agreements were reached with private network providers to provide zero-rated applications as well as educational websites to facilitate remote learning through virtual platforms. This kind of support needs to be praised because it is in keeping with the White Paper on Higher Education which promises 'to redress past inequalities and to transform the higher education system to serve a new social order, to meet pressing national needs, and to respond to new realities and opportunities' (Department of Education, 1997). Even though the additional funding that the institutions of higher learning needed was reduced from 4.6 billion Rand (roughly 308 million USD) to 2.5 billion Rand (approximately 167 million USD), the government through the Department of Higher Education still managed to sustain the redress project by further extending the allowances for NSFAS students to cover the needs of the extended academic year (DHET, 2020). Apart from the group of students whose family income of 350,000 Rand per annum is the limit to be eligible for this aid, those coming from households who do not qualify still battle to make ends meet and these families and students continue to endure the effects of the separate development system. This system of financing higher education serves as a gate keeping mechanism which alienates those who do not meet the criteria because their family income is above the threshold. The challenge they face is that the family income is not sufficient to support and sustain their education. While redress is good for one group, it disadvantages the other and contributes to financial exclusion and dropouts. The latter group does not therefore feel that the hand of Ubuntu is extended to them as they are excluded from redress. This therefore heightens the call 
to promote Ubuntu and reconciliation by being empathetic to the needs of the missing middle. Perhaps one way of doing this is to develop a funding model that is informed by the market needs, social and economic background of the students and their potential. This would create a pool of graduates who can regenerate resources for the wider education sector to sustain itself.

\section{Covid-19 and the Voids of Dealing with the Past in South Africa}

The apartheid system was structured in a manner that provided Black people little access to the infrastructure that facilitated a better life. People in white dominated areas had access to telecommunication systems and networks whereas the same cannot be said of rural, townships and informal settlement communities. This is one of the strategies used to deny Blacks access to the world and to ensure they are not easily connected to the rest of the country and the world, and vice versa. The expectation from these communities was that the TRC would highlight the need for equal opportunities and treatment in all respects for all South Africans because this would promote the spirit of oneness. It is for this reason that Mamdani criticised the TRC for its narrow perspective of political reconciliation as opposed to a more general and national reconciliation. This unfortunately denied the Commission the opportunity to "highlight the bifurcated nature of apartheid as a form of power that governed natives differently from non-natives" (Mamdani, 2002: 34). It is on the basis of this sad reality that during the on-going lockdown students who live in the most remote rural areas are denied access to education, not because they do not have the necessary equipment, but because they reside in spaces that have always suffered exclusion from the telecommunication system.

If the TRC acknowledged that all Black South Africans, who suffered during Apartheid, in these remote areas were denied access to the communication infrastructure as a community by the apartheid regime, perhaps an appropriate recommendation for redress in the form of access could have been made. Consequently, the students would not be suffering exclusion from learning activities due to issues of broadband access and network coverage. This caused many students to relocate to live with other family relatives for the sake of connectivity and access to education. By doing this, they were putting themselves at high risk of contracting the virus but the desire to learn and reach a better position to find jobs and contribute to social and economic development, pushed them to this extent. While the families that accommodated these students demonstrate 
Ubuntu, a principle on which the TRC was foregrounded, a different perspective is held about the Commission. This is a good example of the gaps in the redress programme within the higher education sector.

The pursuit of a just and equal society promised by the TRC report and the constitution proved to be unattainable objectives in the recent future. This is premised on the reality that while strides were made to transform higher education in the quest of a just society, the Covid-19 pandemic exposed the snail pace at which the process has been unfolding. Migration to online learning opportunities did not happen in a seamless way among the 26 public universities. While some universities announced during the end of the second term that they would be moving education to digital platforms in the subsequent semester, many others did not for clear reasons of inequality and lack of resources (Mhlanga \& Moloi, 2020). The differences are not only experienced among these 26 public institutions. Moving to online platforms could not materialise as swiftly as people wished in some institutions because of inequalities among their students. These resulted from the unjust and preferential treatment during apartheid which favoured white institutions.

The current education system which is based on the pillars and principles of constitutional democracy, ought to illustrate appreciation of the spirit of Ubuntu in many respects. Simmonds and du Preez (2014) believe this should not be limited to the curriculum inclusion of concepts such as reconciliation, Ubuntu, social justice, and Human Rights. Rather these concepts ought to be illustrated from the point of access and be meaningfully integrated in inside and outside classroom activities. This may require rethinking these concepts to a great extent to ensure alignment and suitability for the purpose. Such a move may help the sector address the resentment that Horsthemke (2005) raised and which the TRC did not deal with properly. This is mentioned with the full understanding that reconciliation, which is a critical element in the transformation agenda, is a long-term process.

\section{Conclusion}

In this article we argue that apartheid placed all Black South Africanswho did not have voting rights-at a disadvantage, especially in terms of denying them opportunities to be schooled in well-resourced and equipped schools and higher education institutions. For this reason, providing support to a selected group of people, called apartheid victims and their dependents, while ignoring other groups seems to breed dis- 
crimination since during the pre-1994 era all Black children suffered the effects of a racially based educational system despite their background or affiliation, something that was legalised through the Bantu Education Act. Additionally, children from families in the category of households whose total income is below R350,000 benefited from a redress that came in the form of an NSFAS allowance. While this initiative is appreciated as it broadened access to the previously disadvantaged, those whose household income is between R350,000 and R600,000 unfortunately were left to fend for themselves even though their families could not afford to sustain their education costs. The important question is, how effective is this separation of the victims in breeding reconciliation? That is why this article argues that every Black child deserves redress which should not only come through funding, but also through training opportunities, at various national qualifications levels which are guided by the social and economic needs of the country. The positive aspect of this proposed investment is that once students become employers and employees, they will contribute to the economy through value added tax, company tax as well as the pay as you earn tax. This may even help develop citizens who will protect the same economy and the country's infrastructure as well as become actors and advocates of social responsiveness.

One of the positive outcomes of the Covid 19 pandemic is that it has proven that using technology to enable learning is useful and effective (Mhlanga \& Moloi, 2020). Students are able to engage among themselves and the facilitator meaningfully while protecting themselves and their loved ones. However, the biggest challenge in South Africa is that not everyone can benefit from this innovation and creativity because some people live in spaces which have been deliberately isolated from the country's telecommunication system. The situation is worsened by the democratic state that still does not include such communities into the system. This obviously rubs salt into a wound that was beginning to heal. While the country has one of the greatest constitutions that promotes equality and protection of people's dignity, the government does not apply such principles to these communities on the basis that it does not have the means or resources. This causes resentment and ill-feelings among such communities because they feel they are not getting the opportunities promised in the constitution and the TRC report. As a result, we can argue that it is an act of social injustice and further perpetuation of inequalities to expect students who come from such discriminated communities to learn through technology. The pain of exclusion runs deep as it is instilled by a government that promises an equal society through its constitution. This action makes the students more vulnerable to humiliation and susceptible 
to dropping out, not out of their own will but because of the inability of the state to reach out to them and extend the hand of Ubuntu in pursuit of reconciliation.

It is important to note that reconciliation is understood as a long-term process, therefore impossible to materialise over a short period of time. Notwithstanding, care for communities that were previously marginalised ought to be prioritized especially when it comes to access to educational tools which have become a priority. The status quo may derail the very reconciliation process.

\section{References}

Department of Education (1997): White paper number three. Pretoria: Government Printers.

Department of Higher Education (2020): Progress in the post-school education and training sectorin response to Covid-19 epidemic -lockdown level one and towards the end of the academic year. Pretoria: Government Printers.

Dunga, S.H. \& Mncayi, P. (2016): Determinants of the perceptions of free higher education among students at a South African university. In: International Journal of Economics and Finance Studies, 8 (1), 161 - 176.

Horsthemke, K. (2005): Redress and reconciliation in South African education: the case for a rights-based approach. In: Journal of Education, 37 (1), 1-16.

Lambourne, W. (2014): Transformative justice, reconciliation and peacebuilding. In: Buckley-Zistel, S., Beck T.K., Braun C. \& Mieth, F. (Eds.): Transitional justice theories. New York: Routledge.

Mamdani, M. (2002): Amnesty or Impunity? A Preliminary Critique of the Report of the Truth and Reconciliation Commission of South Africa (TRC). In: Diacritics, 32 (3/4), 32-59.

Mlhanga, D \& Moloi T. (2020): COVID-19 and the Digital Transformation of Education: What are we learning on 4IR in South Africa? In: Journal of Research in Education Sciences, 10 (180), 1-11.

Mzangwa, S.Z. (2018): The effects of higher education policy on transformation in post-apartheid South Africa. In: Cogent Education, 6 (1), 1-15.

Nkomo, M., Akoojee, S., \& Motlhanke, S. (2007): Between the rock and the hard place: Understanding the balance between access and efficiency in South African higher education. In: Journal of Asian and African Studies, 42 (5), 399413.

Odero, J.O. (2017): ICT-Based distance education: A study of university students' views and experiences in the early post-Apartheid Stockholm: South Africa. Stockholm: Stockholm University. 
Simmonds, S. \& du Preez, P. (2017) : Discourses shaping human rights education research in South Africa: Future considerations. In: South African Journal of Higher Education, 31 (6), 9-24.

Simmonds, S. \& du Preez, P. (2014): Curriculum, curriculum development, curriculum studies? Problematising theoretical ambiguities in doctoral theses in the education field. In: South African Journal of Education, 34 (2), 1-14.

Ramose, M.B. (2004): In search for an African identity. In: South African Journal Education, 18 (3), 138-160.

Ramose, M. B. (2002): African Philosophy Through Maim. Harare: Mond Books.

TRC (2005): Truth and Reconciliation Commission Report. South Africa.

Uzomah, H.O. (2018): Decolonizing African Educational System as a Panacea for Africa's Educational Advancement in the 21st Century. In: African Renaissance, 15 (1), 29-43.

Van Schalkwyk, F. (2020): Reflections on the public policy university sector and the Covid-19 pandemic in South Africa. In: Studies in Higher Education, 46 (1), 44-58.

Villa-Vicencio, C. (2012): Justice, Media and Memory: The South African Transition. In: Lee. P. \& Thomas, P. (Eds.): Public memory, public media and the politics of Justice. Basingstoke: Palgrave Macmillan.

Villa-Vicencio, C. (2003): No way around the past. In: Sowetan, June 23: 15. 
